\title{
Changes in the fish community of the upper Tiber River after construction of a hydro-dam
}

\author{
Elisabetta FRANCHI, ${ }^{1}$ Antonella CAROSI, ${ }^{1}$ Lucia GHETTI,${ }^{2}$ Daniela GIANNETTO,${ }^{1 *}$ Giovanni PEDICILLO,${ }^{1}$ \\ Laura POMPEI, ${ }^{1}$ Massimo LORENZONI ${ }^{1}$
}

\begin{abstract}
${ }^{1}$ Dipartimento di Biologia Cellulare e Ambientale, Università di Perugia, Via Elce di Sotto, 06123 Perugia; ${ }^{2}$ Servizio Programmazione Forestale, Faunistico-Venatoria and Economia Montana, Regione Umbria, Via M. Angeloni 1, 06123 Perugia, Italy

*Corresponding author: danielagiannetto@libero.it
\end{abstract}

\begin{abstract}
The aim of this study was to assess whether the composition of the fish community in the upper Tiber River Basin changed after the construction of the Montedoglio Reservoir by comparing the composition of the fish assemblages before and after the creation of this structure. Data collected in 2010 from three different sampling sites (one above and two downstream from the dam) were compared with those recorded during previous studies (conducted in 1992) to reveal the change in fish community. In each sampling site, a census of the fish community was conducted, the estimated number of fish of each species was calculated and fish condition was assessed by relative weight. The structure of the communities downstream from Montedoglio Reservoir changed radically after the construction of the barrier, while the fish community upstream from the barrier appeared unaffected by the dam. The release of hypolimnetic cold water from the reservoir, over time, has caused a progressive decreasing of water temperature of the Tiber River. Montedoglio Reservoir and the release of hypolimnetic water had a marked impact on the fish community of the Tiber River because it interrupted the typical longitudinal zonation of the species in the river. In addition, without effective management, this reservoir can pose an increased threat to the native fish species, since it is a source of diffusion of various exotic species.
\end{abstract}

Key words: Montedoglio Reservoir, Tiber River, dam effects, fish community, fish condition.

Received: September 2013. Accepted: November 2013

\section{INTRODUCTION}

River damming is the human activity that most drastically affects freshwater environments (Baxter, 1977; Dynesius and Nilsson, 1994; Dudgeon, 2000). Indeed, a dam on a river induces numerous changes in the aquatic ecosystems both upstream and downstream from it (Mérona et al., 2001; Lorenzoni et al., 2004). By changing water flow, sediment, nutrients, energy and biota, dams interrupt the continuity of rivers and impact most of their important ecological processes (Ligon et al., 1995). Such variations in physical conditions affect the organization, structure and processes of biotic communities in a long stretch of the river both upstream and downstream from the barrier. In many regulated river systems, modified flow regimes are associated to shifts in the thermal regime since dams release hypolimnetic (cold) or epilimnetic (warm) water from thermally stratified reservoirs. Water released from a deep stratum of a reservoir will be slightly warmer than the natural river in the winter, but it can become drastically cooler in the summer. Thermal impacts can be felt at relatively short or long distances downstream from the dam, depending on the exchange with the atmosphere, hydrologic inputs from tributaries and groundwater recharge and dam discharge (Palmer and O'Keeffe, 1989, 1990).
Some studies have showed that dam-induced thermal alterations have significant implications for stream productivity and the reproduction, growth, distribution and assemblage of organisms (Haxton and Findlay, 2008). Generally the biodiversity downstream of a dam is lower than in natural environments because of a reduced temporal heterogeneity in flow and temperature regime (Ward and Stanford, 1983; Jakob et al., 2003). Since aquatic insects and fish use a combination of day length and temperature to synchronize many aspects of their biological cycles, the release of cooler water downstream from dams can influence the spawning of fish and the life history processes of invertebrates (Penaz and Jurayda, 1995). In the long term, the release of hypolimnetic water can cause the selective disappearance of more sensitive species from downstream stretches (Bunn and Arthington, 2002) and fish populations are forced to undergo changes in response to perturbations induced by damming. Dams can also produce a loss of sensitive and endemic species and alterations in dominant taxa (Poff and Zimmerman, 2010; Cibils Martina et al., 2013).

The Montedoglio Reservoir is a man-made lake located in Central Italy (Tuscany and Umbria regions) (Fig. 1) and situated about $33.5 \mathrm{~km}$ from the Tiber River source. This reservoir was planned in the early 1970 s to create a water source for irrigation and drinking water. The construction 
of the dam was completed in 1993 with a planned volume of the reservoir of about $16810^{6} \mathrm{~m}^{3}$ and an available volume of regulation of about $142.510^{6} \mathrm{~m}^{3}$ (Lorenzoni et al., 2004). The reservoir was also equipped with a valve, located about $3 \mathrm{~m}$ from the bottom of the dam, that allows water to return into the Tiber River to ensure the minimum vital flow. Since 2003, the reservoir has released about $7.710^{6} \mathrm{~m}^{3}$ of water per month into the Tiber River in order to exploit the hydroelectric potential of the water and to ensure a sufficient outflow of the river (Di Matteo et al., 2006).

The main aim of this research was to assess the changes in the composition of the fish community in the upper Tiber River Basin due to the construction of the Montedoglio Reservoir. A further aim was to compare the relative weight of the main fish species upstream and downstream from the dam to evaluate the potential effects of the dam on health of individuals.

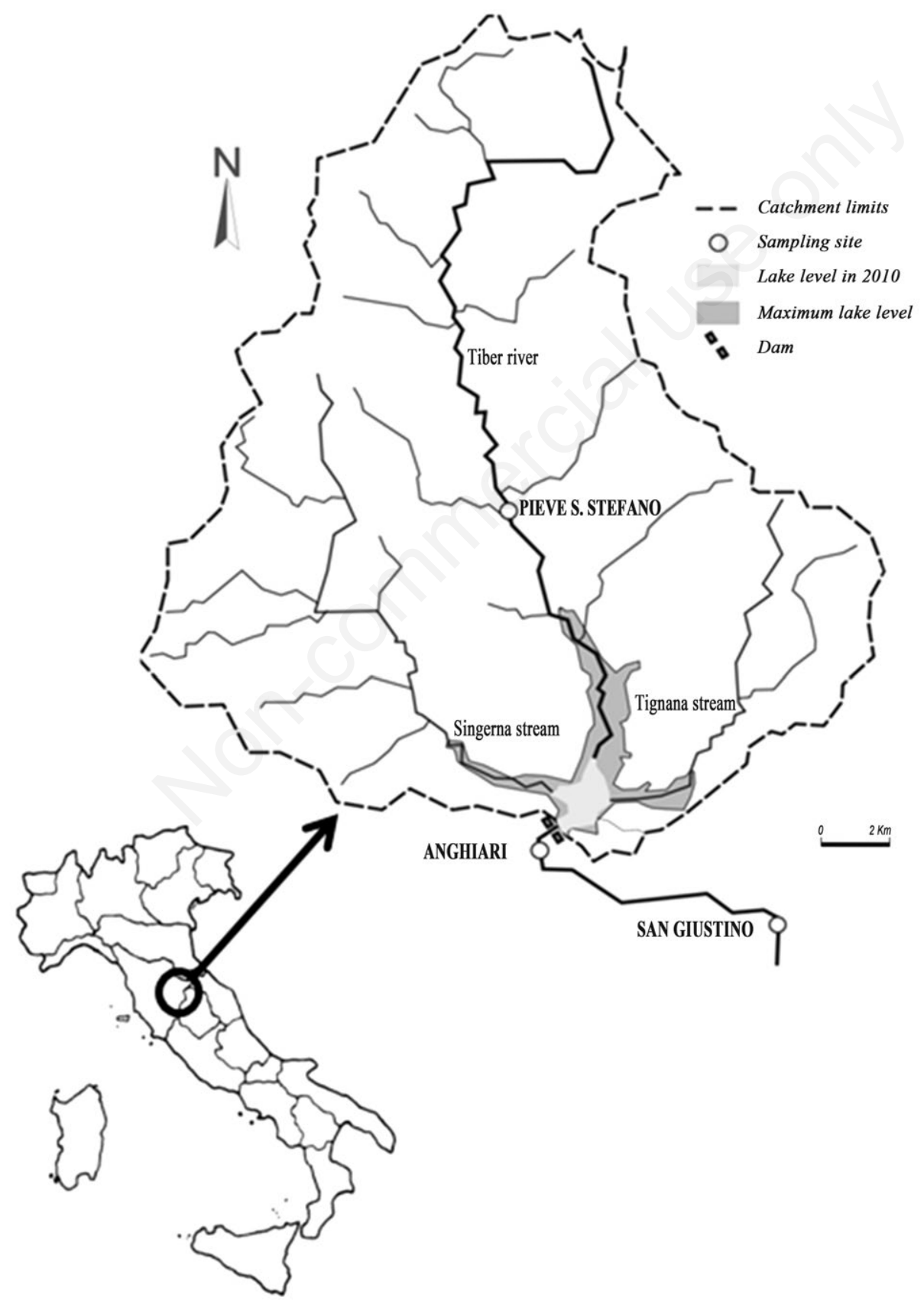

Fig. 1. Study area and locations of the sampling sites. 


\section{METHODS}

\section{Study area}

Data were collected in three different sampling sites (one upstream from the Montedoglio Reservoir and two downstream) (Fig. 1) along the Tiber River, which is the third-longest $(405 \mathrm{~km}$ ) river in Italy. The first sampling site (Pieve S. Stefano) was located $23 \mathrm{~km}$ downstream from the Tiber River source and about $7 \mathrm{~km}$ upstream from the Montedoglio Reservoir. In this location the Tiber River was $5.7 \mathrm{~m}$ wide, $0.25 \mathrm{~m}$ depth and a stretch of $62.10 \mathrm{~m}$ was sampled. The second sampling site (Anghiari) was the closest to Montedoglio Reservoir being localized about $1.5 \mathrm{~km}$ downstream from the dam and $35 \mathrm{~km}$ from the river source. In this site the Tiber had a deep of $0.45 \mathrm{~m}$, a wide of 21.2 $\mathrm{m}$ and a stretch of $96.20 \mathrm{~m}$ was sampled. The third sampling site (S. Giustino) was located about $43 \mathrm{~km}$ from the Tiber River source and $10 \mathrm{~km}$ downstream from the dam. Here the river had a width of $17.5 \mathrm{~m}$, a deep of $0.45 \mathrm{~m}$ and a stretch $113 \mathrm{~m}$ long was sampled.

\section{Data collection}

Data were collected in October 2010 and compared with those recorded during previous studies conducted in 1992 in the same month (Lorenzoni et al., 1994; Santucci et al., 1994), when the dam was still under construction.

In both periods the census of fish fauna was carried out by electrofishing by wading the river from downstream to upstream during daylight, using the removal method (Moran, 1951; Zippin, 1956). Immediately after capture, all specimens were identified at the species level, counted, measured for total length to the nearest $1 \mathrm{~mm}$ and weighed to the nearest $0.1 \mathrm{~g}$. The estimated number of fish at each sampling site was calculated using the Moran-Zippin method (Moran, 1951; Zippin, 1956, 1958): the number of fish was estimated on the basis of specimens captured in two consecutive steps (Marconato, 1991). The density (specimens $\mathrm{m}^{-2}$ ) was calculated by dividing the estimated number by the surface areas of the sampling sites. In order to identify changes in the composition of the fish community from 1992 to 2010, the fish species were divided into categories according to Huet (1954) who grouped the fish species on the basis of their ecological requirements (Mearelli et al., 1995) (Tab. 1). However, in addition to the 4 categories suggested by Huet (1954) (rheophilic cyprinids, limnophilic cyprinids, predators and salmonids), to further illustrate the degree of change that occurred after the damming, another 2 categories were created: first, the species not belonging to the family of Cyprinids (Cobitis bilineata, Padogobius nigrigans and Padogobius bonelli) but inhabiting the same river stretches as the rheophilic cyprinids species (Lorenzoni et al., 2010) and showing ecological requirements similar to them (Giannetto et al., 2013) were grouped as other species (Carosi et al., 2006); second, Telestes muticellus, was not grouped together with other rheophilic cyprinid (because when compared with such species, it is better adapted to colder water and it can inhabit the same river stretches as salmonids) but considered alone in the category Italian raffle dace (Tab. 1).

\section{Estimation of fish condition}

Relative weight $\left(\mathrm{W}_{\mathrm{r}}\right)$ (Wege and Anderson, 1978) was used to evaluate the condition of fish specimens belonging to five species: Barbus tyberinus Bonaparte 1839; Squalius squalus (Bonaparte 1837); Rutilus rubilio (Bonaparte 1837); Telestes muticellus (Bonaparte 1837) and Salmo trutta (Linnaeus 1758). For each specimens of the selected 5 species, $\mathrm{W}_{\mathrm{r}}$ was calculated using the following equation:

$$
\mathrm{W}_{\mathrm{r}}=\left(\mathrm{W} / \mathrm{W}_{\mathrm{s}}\right) 100
$$

where $\mathrm{W}$ is body weight $(\mathrm{g})$ and $\mathrm{W}_{\mathrm{s}}$ is the standard weight determined on the basis of a standard weight equation proposed for each species (Angeli et al., 2010; Giannetto et al., 2011a, 2011b). For these species for the sampling sites of Pieve S. Stefano and S. Giustino, $t$-Student test was used to test the difference in $\mathrm{W}_{\mathrm{r}}$ values between 1992 and 2010. Before to apply the $t$-test, the normality of data distribution was assessed by means of the Wilk-Shapiro test.

The Anghiari sampling site was not considered since only salmonids and no cyprinid species were collected in 2010; subsequently, no comparison with the data collected

Tab. 1. Species composition of the ecological categories used in the research.

\begin{tabular}{ll}
\hline Ecological category & Species \\
\hline Rheophilic cyprinids & $\begin{array}{l}\text { Barbus barbus (Linnaeus, 1758); Barbus tyberinus Bonaparte, 1839; Protochondrostoma genei (Bonaparte, 1839); } \\
\text { Squalius squalus (Bonaparte, 1837); Rutilus rubilio (Bonaparte, 1837). }\end{array}$ \\
Limnophilic cyprinids & Cyprinus carpio Linnaeus 1758; Scardinius erythrophthalmus (Linnaeus, 1758). \\
Predators & Anguilla anguilla (Linnaeus, 1758); Ameiurus melas (Rafinesque, 1820); Perca fluviatilis Linnaeus, 1758. \\
Salmonids & Salmo trutta Linnaeus, 1758; Thymallus thymallus (Linnaeus, 1758). \\
Italian raffle dace & Telestes muticellus (Bonaparte, 1837). \\
Other species & Padogobius bonelli (Bonaparte, 1846); Padogobius nigricans (Canestrini, 1867); Cobitis bilineata Canestrini, 1865. \\
\hline
\end{tabular}


in 1992 or with the fish communities found in the other sampling sites was possible.

\section{Water temperature analysis}

To analyse the change that occurred over time in thermal conditions downstream from the dam, due to the release of water from the reservoir, water temperature measured in the two different periods (1992 and 2010) was also compared. In both years, in the month of October, the temperature was measured in the two sampling sites downstream from the dam (Anghiari and S.
Giustino) and in two additional localities further downstream from the dam (localized $21 \mathrm{~km}$ and $76 \mathrm{~km}$ from the Montedoglio Reservoir) (one measurement each sampling sites). The values of temperature were plotted in function of the distance (in $\mathrm{km}$ ) from the source.

\section{RESULTS}

Comparing the values of density of the species calculated in the two different periods (1992 and 2010), the fish community upstream of the dam (Pieve S. Stefano) showed very little changes from 1992 to 2010 (Fig. 2); in

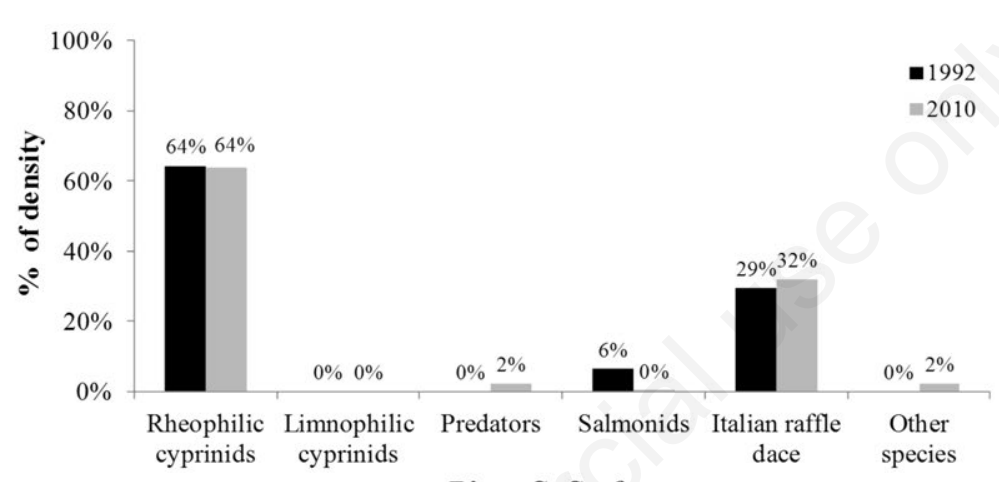

Pieve S. Stefano

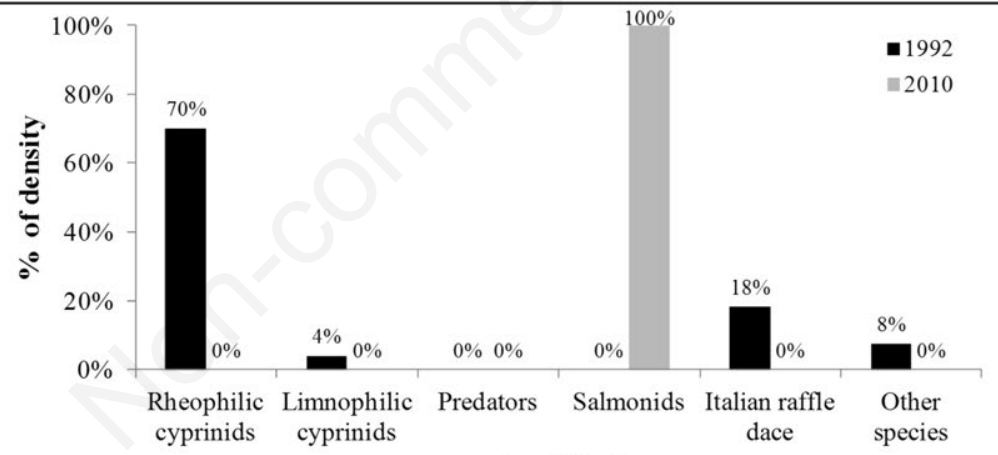

Anghiari

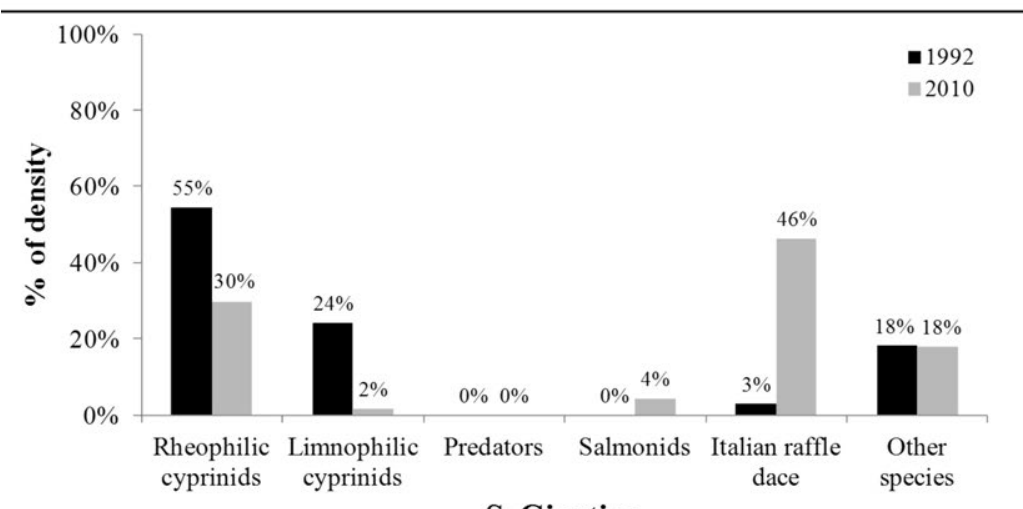

S. Giustino

Fig. 2. Comparison of the composition of fish community (expressed as percentage of density for each fish category) found in the three sampling sites before (1992) and after (2010) the construction of the dam. 
both years, the dominant category was rheophilic cyprinids. In contrast, in the sampling sites immediately downstream from the dam (Anghiari) a fundamental change in the fish communities was observed: while in 1992 the fish community was dominated by rheophilic cyprinids $(70 \%)$, in 2010 this group was totally replaced by salmonids (100\%) (Fig. 2). In the last sampling site, localized $10 \mathrm{~km}$ downstream from the dam (S. Giustino), the changes were less marked but the effects of the reservoir were still evident with a decrease in the limnophilic and rheophilic cyprinids and a consequential increase in the dominance of Telestes muticellus (Fig. 2).

\section{Fish condition}

According to the Wilk-Shapiro test, a normal distribution of fish condition data resulted for all the 4 species considered ( $\mathrm{W}=0.987, \mathrm{P}=0.174$ for Barbus tyberinus; $\mathrm{W}=0.954, \mathrm{P}=0.071$ for Rutilus rubilio; $\mathrm{W}=0.927, \mathrm{P}=0.085$ for Squalus squalus; $\mathrm{W}=0.992, \mathrm{P}=0.166$ for Telestes $m u$ ticellus) and this validate the use of $t$-test to compare the change in condition between the two period. At Pieve S. Stefano, the mean $\mathrm{W}_{\mathrm{r}}$ values of each species were very similar and not significantly different for Barbus tyberinus ( $t=3.677, \mathrm{P}=0.056)$, Rutilus rubilio $(t=1.415, \mathrm{P}=0.237)$, Squalus squalus $(t=2.271, \mathrm{P}=0.134)$ and Telestes muticellus $(t=0.045, \mathrm{P}=0.831)$ (Tab. 2).

In contrast, in the site immediately downstream from the dam (S. Giustino), the $\mathrm{W}_{\mathrm{r}}$ values were significantly higher in 2010 than in 1992 revealed a highly significant differences between the value of condition for Barbus tyberinus ( $t=20.882, \mathrm{P}<0.001)$, Squalus squalus ( $t=39.172$, $\mathrm{P}<0.001)$, and Telestes muticellus $(t=8.465, \mathrm{P}=0.005)$ while no significant differences were found for Rutilus rubilio ( $t=0.641, \mathrm{P}=0.800$ ) (Tab. 2). Moreover, the mean values of $\mathrm{W}_{\mathrm{r}}$ calculated for these cyprinid species in 2010 were significantly higher in the sampling sites down- stream from the dam (S. Giustino) for Barbus tyberinus ( $t=5.713, \mathrm{P}=0.019)$, Squalus squalus $(t=4.016, \mathrm{P}<0.001)$ and Telestes muticellus $(t=10.983, \mathrm{P}=0.001)$ (Tab. 2). In the Anghiari sampling site, the mean $\mathrm{W}_{\mathrm{r}}$ value for Salmo trutta resulted close to $100,98.721$ (Tab. 2).

\section{Water temperature analysis}

Analysis of water temperature revealed a generalized cooling of the upper stretch of the river, which became progressively more accentuated over time (Fig. 3). This reduction of water temperature was evident in 2010, when the reservoir reached its definitive level. The temperature drop was greatest in Anghiari, the sampling site immediately downstream of the reservoir $(35 \mathrm{~km}$ from the Tiber River source), where a difference of up to $8.5^{\circ} \mathrm{C}$ between 1992 and 2010 was recorded. On moving further downstream, the variation was gradually attenuated (Fig. 3).

\section{DISCUSSION}

One of the most immediate effects of dam construction on a fish fauna is the introduction of obstacle to upstream migration. However, reservoirs can have also fundamental effects on the structure of fish communities by changing the habitat river downstream from the dam and this is particularly marked when deep reservoirs release hypolimnetic water (Lorenzoni et al., 2004). Habitat controls the natural longitudinal distribution of fish and changes in its characteristics result in alterations of the fish assemblage (Huet, 1949, 1954, 1962; Arunachalam, 2000; Bunn and Davies, 2000).

The results of the present study showed that the construction of the dam on the Tiber River had no apparent effect on fish community structure upstream of the reservoir, but, in contrast it has strongly influenced the community downstream. These results are in line with those of studies of other reservoirs (Lelek et al., 1973; Petts,

Tab. 2. Descriptive statistics of relative weight for sampling sites and study periods.

\begin{tabular}{llcccccc}
\hline Species & Sampling site & \multicolumn{3}{c}{1992} & \multicolumn{2}{c}{2010} \\
\cline { 2 - 7 } & & $\mathrm{n}$ & $\mathrm{Mean} \mathrm{W}_{\mathrm{r}}$ & $\mathrm{SD}$ & $\mathrm{n}$ & $\mathrm{Mean}_{\mathrm{r}}$ & $\mathrm{SD}$ \\
\hline B. tyberinus & Pieve S. Stefano & 316 & 92.397 & 11.686 & 73 & 95.216 & 9.557 \\
& S. Giustino & 176 & 90.141 & 9.358 & 15 & 101.511 & 7.768 \\
\hline S. squalus & Pieve S. Stefano & 108 & 98.888 & 12.043 & 78 & 96.304 & 10.803 \\
& S. Giustino & 313 & 88.977 & 14.259 & 36 & 104.278 & 10.039 \\
\hline R. rutilus & Pieve S. Stefano & 22 & 94.480 & 12.164 & 65 & 99.723 & 19.372 \\
& S. Giustino & 316 & 91.374 & 19.213 & 7 & 93.232 & 18.957 \\
\hline T. muticellus & Pieve S. Stefano & 132 & 97.977 & 14.712 & 56 & 98.457 & 12.586 \\
& S. Giustino & 10 & 89.581 & 22.641 & 82 & 107.702 & 18.088 \\
\hline S. trutta & Anghiari & - & - & - & 82 & 98.721 & 13.140 \\
\hline N. sample & & & & &
\end{tabular}

$N$, sample size; $W_{r}$, relative weight; $S D$, standard deviation. 
1988; de Mèrona et al., 2001). More specifically, in the present study, in 1992, in the sampling site located immediately downstream from the dam, the fish community was dominated by the rheophilic cyprinids species typical of the mid-upper reaches of the Tiber River (B. tyberinus, $P$. genei, R. rutilus and $S$. squalus) (Lorenzoni et al., 2006); in contrast, in 2010, the fish community of Anghiari was constituted entirely of salmonids and the only species sampled were $S$. trutta and T. thymallus. A similar pattern was also observed in the Colorado River (USA) where the construction of dam had resulted in a decline of native fish community and its replacement by Salmo spp. (Holden and Stalnaker, 1975). In Central Italy, S. trutta typically inhabits the small tributaries of the Tiber River localized in mountain because this species is a frigo-stenothermal stenoxybiont and less adapted to the environmental characteristics of the main stretch of the Tiber River (Lorenzoni et al., 2006). This species probably benefitted from the recent decrease of water temperature that occurred downstream from the Montedoglio Reservoir as demonstrated by the mean values of relative weight calculated for this species that reflected a good status of condition (Anderson, 1980). The same increasing of condition for the fish populations downstream from the dam, observed in the present study, were also reported by
Crisp et al. (1983) for the Tees River (UK) after the construction of the Cow Green Reservoir. In that case, quantitative changes in the composition of fish stomach contents also occurred after the construction of the dam (Crisp et al., 1978, 1984). With regard to T. thymallus, its distribution is actually limited to the watercourses of North Italy (Zerunian, 2002) and the presence of this species in the Tiber River was due to recent introduction. In the past, several efforts to introduce this species into other waterways have been attempted but without success; the presence of the T. thymallus in the Tiber River was surely facilitated by the change in its environmental conditions due to the reservoir. In the other sampling site downstream from the dam (S. Giustino) the fish community also proved to have been modified since 1992 with a drastic decrease of the dominance of rheophilic and limnophilic cyprinids and a high increase in Italian ruffle dace. This species benefitted from the changes induced by the reservoir, probably because, among all the cyprinids present, it is the one that adapts best to cold water (Bianco, 1996).

Water temperature is one of the environmental factors that most strongly influences the distribution of fish fauna (Martinez et al., 1994); changes in the thermal regime and in the water quality result in changes in primary produc-

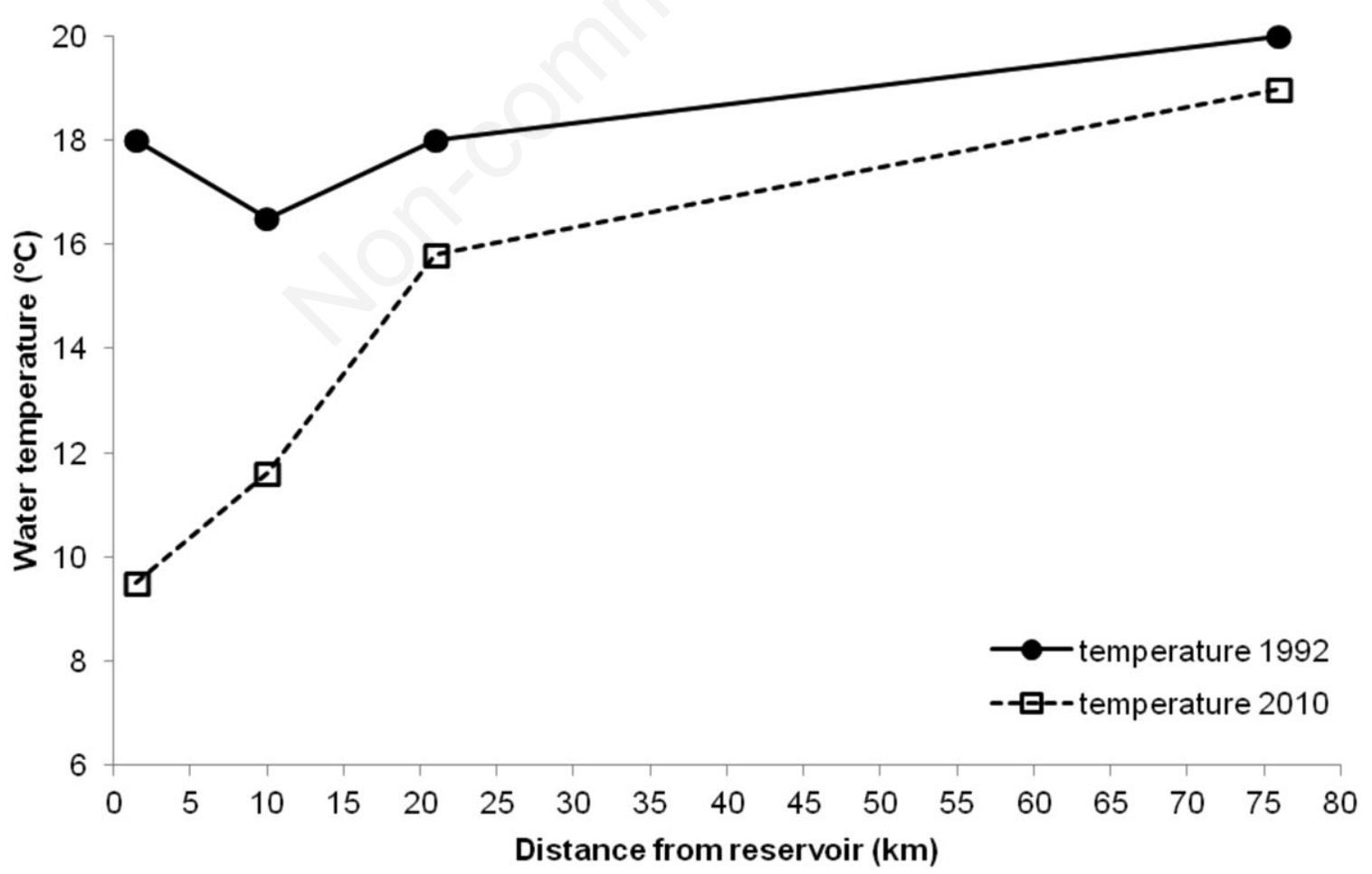

Fig. 3. Comparison between water temperature $\left({ }^{\circ} \mathrm{C}\right)$ in the Tiber River in 1992 and 2010 in relation to the distance from the reservoir of the sampling sites. 
tion, with long-term implications for the fish community and other organisms at the top of the food chain (McCartney et al., 2001). For example, a substantial number of large dams have intentionally been used to manage thermal regimes through the selective release of cold water from deep reservoirs, in order to promote fishing opportunities for some species of salmonids (Olden and Naiman, 2010). Similarly, the radical change in the distribution of fish fauna observed in the Tiber River downstream of the Montedoglio Reservoir can be attributed to the decrease of the water temperature due to the release of cold water from the hypolimnion. Immediately downstream from the Montedoglio Reservoir, the variation in the water temperature led to the loss of optimal conditions for the survival of rheophilic cyprinids (Huet, 1949, 1954, 1962; Mearelli et al., 1995) and facilitated colonization by salmonids.

Upstream from the dam (Pieve S. Stefano), the condition of the species investigated remained unchanged between 1992 and 2010. On the contrary downstream of the dam (S. Giustino) an increase in condition was observed when compared with the populations inhabiting areas upstream from the dam and with the state before the construction of the reservoir. The same scenario was reported by McCartney et al. (2001) who observed that fish populations increased in the tailwaters of some dams because the regulated thermal regime raises the local primary production (i.e., plankton) and observed lower turbidity was favourable for some fish species (e.g., salmonids).

\section{CONCLUSIONS}

The modification of thermal conditions of rivers due to the release of hypolimnetic water from reservoirs has a marked impact on river because it interrupts the natural fish zonation (Huet, 1949; Mearelli et al., 1995). In this way, species traditionally inhabiting the upper stretches of the river (e.g., salmonids) may colonize the downstream sectors disadvantaging the species typical of the barbel zone. Moreover, the increase of condition in fish downstream from the dam could easily be attributed to an increase in the availability of nutrients as a result of the decomposition and mineralization of organic substances inside the reservoir.

The original fish community of the upper part of Tiber River consists of species with a high conservation value (Lorenzoni et al., 2006) comprising many of the endemics of the Tuscany and Lazio district (Bianco, 1996) and already threatened by various human pressures (IUCN, 2011). In this context, the construction of the Montedoglio Reservoir raises another potential threat for these species: in absence of careful management, the reservoir may represent a source of diffusion of various exotic species in the downstream river stretches (Lorenzoni et al., 2004) potentially raising the already high level of zoogeographic pollution that now characterises the Tiber River (Bianco, 1990; Lorenzoni et al., 2006, Giannetto et al., 2012).

\section{REFERENCES}

Anderson RO, 1980. Proportional stock density (PSD) and relative weight $\left(\mathrm{W}_{\mathrm{r}}\right)$ : interpretive indices for fish populations and communities, chapter 27-33. In: S. Gloss and B. Shupp (eds.), Practical fisheries management: more with less in the 1980's. American Fisheries Society, New York.

Angeli V, Bicchi A, Carosi A, Spigonardi MP, Pedicillo G, Lorenzoni M, 2010. [Calcolo del peso standard $\left(\mathrm{W}_{\mathrm{s}}\right)$ per le principali specie ittiche del bacino del fiume Tevere]. [Article in Italian]. Studi Trentini di Scienze Naturali 87: 141-143.

Arunachalam M, 2000. Assemblage structure of stream fishes in the Western Ghats (India). Hydrobiologia 430:1-31.

Baxter RM, 1977. Environmental effects of dams and impoundments. Annu. Rev. Ecol. Syst. 8:255-283.

Bianco PG, 1990. [Proposta di impiego di indici e coefficienti per la valutazione dello stato di degrado dell'ittiofauna autoctona delle acque dolci]. [Article in Italian]. Riv. Idrobiol. 29:130-149.

Bianco PG, 1996. [Inquadramento zoogeografico dell'ittiofauna continentale autoctona nell'ambito della sottoregione euromediterranea]. [Article in Italian]. Atti IV Convegno Nazionale AIIAD 145-170.

Bunn SE, Arthington AH, 2002. Basic principles and ecological consequences of altered flow regimes for aquatic biodiversity. Environ. Manage. 30:492-507.

Bunn SE, Davies PM, 2000. Biological processes in running waters and their implications for the assessment of ecological integrity. Hydrobiologia 422/423:61-70.

Carosi A, Ghetti L, Pedicillo G, Lorenzoni M, 2006. [Distribuzione e abbondanza di Barbus tyberinus Bonaparte, 1839 nel bacino umbro del fiume Tevere]. [Article in Italian]. Proceedings $16^{\text {th }}$ Meet. Italian Society of Ecology.

Cibils Martina L, Principe R, Gari N, 2013. Effect of a dam on epilithic algal communities of a mountain stream beforeafter dam construction comparison. J. Limnol. 72:e7.

Crisp DT, Mann RHK, McCormack JC, 1978. The effects of impoundment and regulation upon the stomach contents of fish at Cow Green, upper Tees dale. J. Fish. Biol. 12:287-301.

Crisp DT, Mann RHK, Cubby PR, 1983. Effects of regulation of the River Tees upon fish populations below Cow Green Reservoir. J. Appl. Ecol. 20:371-386.

Crisp DT, Mann RHK, Cubby PR, 1984. Effects of impoundment on fish populations in afferent streams at Cow Green Reservoir. J. Appl. Ecol. 35:882-892.

de Mèrona B, Mendes dos Santos G, Goncalves de Almeida R, 2001. Short term effects of Turcuruì Dam (Amazonia, Brasil) on the trophic organization of fish communites. Environmental Biology of Fishes 60:375-392.

Di Matteo L, Dragoni W, Pierucci L, Valigi D, 2006. [Studio idrogeologico e climatico del bacino del lago di Montedoglio (Tevere, Arezzo - Italia Centrale)]. [Article in Italian]. Giorn. Geol. Appl. 3:32-38.

Dudgeon D, 2000. The ecology of tropical Asian rivers and streams in relation to biodiversity conservation. Annu. Rev. Ecol. Syst. 31:239-263. 
Dynesius M, Nilsson C, 1994. Fragmentation and flow regulation of river systems in northern third of the world. Science 266:753-762.

Giannetto D, Carosi A, Franchi E, Pedicillo G, Pompei L, Lorenzoni M, 2011a. Proposed standard weight $\left(\mathrm{W}_{\mathrm{s}}\right)$ equations for Telestes muticellus (Bonaparte, 1837) in the Tiber River Basin. Cybium 35:141-147.

Giannetto D, Carosi A, Franchi E, Pedicillo G, Pompei L, Lorenzoni M, 2012. Assessing the impact of non-native freshwater fishes on native species using relative weight. Knowl. Manag. Aquat. Ec. 404:03.

Giannetto D, Carosi A, Ghetti L, Pedicillo G, Pompei L, Lorenzoni M, 2013. Ecological traits of Squalius lucumonis (Actinopterygii, Cyprinidae) and main differences with those of Squalius squalus in the Tiber River Basin (Italy). Knowl. Manag. Aquat. Ec. 409:04.

Giannetto D, La Porta G, Maio G, Pizzul E, Turin P. Lorenzoni M, 2011b. Proposed standard mass equations for European chub Leuciscus cephalus in Italy. J. Fish Biol. 78:1890-1899.

Haxton TJ, Findlay CS, 2008. Meta-analysis of the impacts of water management on aquatic communities. Can. J. Fish Aquat. Sci. 65:437-447.

Holden PB, Stalnaker CB, 1975. Distribution and abundance of mainstream fishes of the middle and upper Colorado River Basins. T. Am. Fish Soc. 104217-231.

Huet M, 1949. [Aperçu des relations entre la pente et les populations piscicoles dans les eaux courantes]. [Article in French]. Rev. Suisse Hydr. 11:332-351.

Huet M, 1954. [Biologie, profils en long et en traverse des eaux courantes]. [Article in French]. B. Fr. Peche Piscic. 175:41-53.

Huet M, 1962. [Influence du courant sur la distribution des poissons dans les eaux courantes]. [Article in French]. Rev. Suisse Hydr. 24:412-432.

IUCN, 2011. IUCN red list of threatened species, ver. 2011.1. Available from: www.iucnredlist.org

Jakob C, Robinson CT, Uehlinger U, 2003. Longitudinal effects of experimental floods on stream benthos downstream from a large dam. Aquat. Sci. 65:223-231.

Lelek A, El-Zarka S, 1973. Ecological comparison of the preimpoundment and postimpoundment fish faunas of the River Niger and Kainji Lake, Nigeria, p. 655-660. In: Ackermann W.C, White G.F. and Worthington E.B. (eds.), Man-made lakes: their problems and environmental effects. American Geophysical Union, Washington.

Ligon FK, Dietrich WE, Trush WJ, 1995. Downstream ecological effects of dams: a geomorphic perspective. BioScience 45:183-192.

Lorenzoni M, Mearelli M, Carosi A, Giovinazzo G, Petesse ML, Santucci A, Bazzurro F, 1994. [Studio sulla rete idrica dell'alto bacino del fiume Tevere (Italia centrale): comunità ittiche]. [Article in Italian]. Riv. Idrobiol. 33:229-275.

Lorenzoni M, Carosi A, Giovinazzo G, Petesse ML, Mearelli M, 2004. The fish fauna in the Montedoglio Reservoir (Tuscany, Italy) five years after its construction. Echohydrol. Hydrobiol. 4:135-146.

Lorenzoni M, Mearelli M, Ghetti L, 2006. Native and exotic fish species in the Tiber River watershed (Umbria-Italy) and their relationship to the longitudinal gradient. B. Fr. Peche Piscic. 382:19-44.

Lorenzoni M, Ghetti L, Carosi A, Dolciami R, 2010. [La fauna ittica e i corsi d'acqua dell'Umbria]. [Book in Italian]. Regione Umbria, Perugia: 288 pp.

Marconato A, 1991. [Metodi per lo studio della struttura delle popolazioni ittiche delle acque interne: la densità di popolazione. Supplemento alle ricerche di biologia della selvaggina]. [Article in Italian]. INBS 16:7-18.

Martinez PJ, Chart TE, Trammel MA, Wullschleger JG, Bergersen EP, 1994. Fish species composition before and after construction of a main stem reservoir on the White River, Colorado. Envir. Biol. Fish. 40: 27-239.

McCartney MP, Sullivan C, Acreman MC, 2001. Ecosystem impacts of large dam. Background Paper Nr. 2. Prepared for IUCN/ UNEP/WCD. Available from: http://intranet.iucn. org/webfiles/doc/archive/2001/iucn852.pdf

Mearelli M, Giovinazzo G, Lorenzoni M, Petesse ML, Carosi A, 1995. [Zonazione ittica dei corsi d'acqua del bacino del fiume Tevere]. [Article in Italian]. Atti S.It.E. 16:669-671.

Moran PAP, 1951. A mathematical theory of animal trapping. Biometrika 38:307-311.

Olden JD, Naiman R, 2010. Incorporating thermal regimes into environmental flows assessment: modifying dam operations to restore freshwater ecosystem integrity. Freshwater Biol. 55:86-107.

Palmer RW, O'Keeffe JH, 1989. Temperature characteristics of an impounded river. Hydrobiologia 116:471-485.

Palmer RW, O'Keeffe JH, 1990. Downstream effect of impoundments on the water chemistry of the Buffalo River (Eastern Cape), South Africa. Hydrobiologia 202:71-83.

Petts GE, 1988. Impounded rivers: perspectives for ecological management. Wiley \& Sons, New York: 344 pp.

Poff NL, Zimmerman JKH, 2010. Ecological responses to altered flow regimes: a literature review to inform the science and management of environmental flows. Freshwater Biol. 55:194-205.

Santucci A, Petesse ML, Mearelli M, Lorenzoni M, Bazzurro F, 1994. [Indagini sulla rete idrica dell'alto bacino del fiume Tevere (Italia centrale): analisi delle caratteristiche territoriali, idrologiche e della qualità dell'acqua]. [Article in Italian]. Riv. Idrobiol. 33:151-205.

Ward JV, Stanford JA, 1983. The serial discontinuity concept of lotic ecosystems, p. 29-42. In: T.D. Fontaine and S.M. Bartell (eds.), Dynamics of lotic ecosystems. Ann Arbor Science Publ., Ann Arbor, USA.

Wege GJ, Anderson RO, 1978. Relative weight $\left(\mathrm{W}_{\mathrm{r}}\right)$ : a new index of condition for largemouth bass, p. 79-91. In: G.D. Novinger and J.G. Dillard (eds.), New approaches to the management of small impoundments. American Fisheries Society Special Publ.

Zerunian S, 2002. [Pesci delle acque interne italiane]. [Article in Italian]. Quad. Cons. Natura 20:122-127.

Zippin C, 1956. An evaluation of removal method of estimating animal population. Biometrics 12:163-189.

Zippin C, 1958. The removal method of population estimation. J. Wildlife Manage. 22:82-90. 